\title{
Induced Mutation
}

National Cancer Institute

\section{Source}

National Cancer Institute. Induced Mutation. NCI Thesaurus. Code C40987.

Any mutation that occurs in response to inducing agents, including radiation, viral infection, and a broad variety of mutagenic chemicals. 